\title{
Recent Advances on Heat Exchanger-Absorber Design
}

\author{
Fan Y and Luo L* \\ Laboratoire de Thermique ET Energie de Nantes, University of Nantes, France
}

Submission: June 17, 2017; Published: June 27, 2017

*Corresponding author: Luo L, Laboratoire de Thermique et Energie de Nantes, University of Nantes, La Chantrerie, Rue Christian Pauc, France, Tel: +33240683167; Fax: +33 240683141; Email: lingai.luo@univ-nantes.fr

\section{Abstract}

This paper presents the state-of-the-art and recent advances on the design of integrated heat exchanger-absorbers. A variety of geometries of HEX-absorber have been surveyed and categorized, including horizontal tubes, vertical tubes, plate type and others. A special focus is made on the use of different techniques to intensify the heat and mass transfers.

Keywords: Heat exchanger; Absorption; Heat and mass transfer; Intensification

Abbreviations: HE: Heat exchanger; HMT: Heat and mass transfer

\section{Integrated Heat Exchanger-Absorber}

Absorption process is now widely used for solar or waste heat driven cooling or refrigeration applications [1, 2], for heat or cooling transportation over long distance [3] and for solar energy storage $[4,5]$. The key component in an absorption machine is the absorber where the liquid solution (as absorbent) contacts with and absorbs gas vapor (as absorbent).

The heat removal efficiency of the absorption heat determines the absorption rate in the absorber and consequently the global COP of absorption machines. As a result, the integration of absorption and heat exchange functions in a single device, the so called HEX-absorber (also named as absorber-heat transformer), is a natural and reasonable choice.

Table 1: Selected studies on integrated HEX-absorber with heat and mass transfer intensification.

\begin{tabular}{|c|c|c|c|c|c|c|c|c|}
\hline Study & N/E & $\begin{array}{l}\text { Geometry/ } \\
\text { Dimension }\end{array}$ & Material & Working Medium & $\begin{array}{c}\text { Flow } \\
\text { Configuration }\end{array}$ & $\begin{array}{l}\text { Intensification } \\
\text { Techniques }\end{array}$ & $\begin{array}{l}\text { Performance } \\
\text { Improvement }\end{array}$ & $\begin{array}{c}\text { Ther } \\
\text { mal } \\
\text { comp } \\
\text { atibility } \\
\theta(\mathrm{kW} \\
\cdot \mathrm{m}- \\
3 \cdot \mathrm{K}-1)\end{array}$ \\
\hline $\begin{array}{l}\text { Hoffmann } \\
\text { et al. [6] }\end{array}$ & E & $\begin{array}{l}24 \text { horizontal } \\
\text { tubes in } \\
\text { serpentine }\end{array}$ & $\begin{array}{l}\text { Copper tubes } \\
\text { Glass column }\end{array}$ & $\begin{array}{l}\text { Tube inside: cooling } \\
\text { water } \\
\text { Tube outside: LiBr film } \\
\text { and steam }\end{array}$ & $\begin{array}{l}\text { Countercurrent } \\
\text { flow for } \\
\text { solution-gas } \\
\text { contact } \\
\text { Cross- } \\
\text { countercurrent } \\
\text { for heat } \\
\text { exchange }\end{array}$ & $\begin{array}{l}\text { Tube inside: } \\
\text { helical rods } \\
\text { Tube outside: } \\
\text { knurled surface } \\
\text { Surfactant } \\
\text { additives for the } \\
\text { LiBr solution }\end{array}$ & $\begin{array}{l}20 \% \text { to } 42 \% \\
\text { higher h } \\
\text { (film) with } \\
\text { knurled tubes } \\
\text { compared to } \\
\text { plain tubes } \\
60 \% \text { to } 140 \% \\
\text { higher (film) } \\
\text { with surfactant } \\
\text { additives }\end{array}$ & - \\
\hline $\begin{array}{c}\text { Islam et al. } \\
\text { [10] }\end{array}$ & N/E & $\begin{array}{c}24 \text { horizontal } \\
\text { tubes } d_{\mathrm{i}}=0.017 \\
\mathrm{~mm} ; \mathrm{d}_{\mathrm{o}}=0.019 \\
\mathrm{~mm} ; \mathrm{l}=160 \mathrm{~mm} \\
\mathrm{~A}=0.23 \mathrm{~m}^{2} ; \\
\mathrm{V}=7.94 \times 10-2 \mathrm{~m}^{3}\end{array}$ & $\begin{array}{l}\text { Glass vessel } \\
\text { Copper tubes }\end{array}$ & $\begin{array}{l}\text { LiBr solution and steam } \\
\text { Cooling water }\end{array}$ & $\begin{array}{l}\text { Countercurrent } \\
\text { flow for } \\
\text { liquid-gas } \\
\text { contact Cross- } \\
\text { countercurrent } \\
\text { flow for heat } \\
\text { exchange }\end{array}$ & $\begin{array}{l}\text { Short copper } \\
\text { guiding fins } \\
\text { installed } \\
\text { between tubes } \\
\text { for film inverting }\end{array}$ & $\begin{array}{l}100 \% \text { increase } \\
\text { in vapor } \\
\text { absorption } \\
\text { rate with the } \\
\text { film inverting } \\
\text { design } \\
\text { compared to } \\
\text { conventi onal } \\
\text { design }\end{array}$ & - \\
\hline
\end{tabular}




\section{Recent Advances in Petrochemical Science}

\begin{tabular}{|c|c|c|c|c|c|c|c|c|}
\hline $\begin{array}{l}\text { Goel and } \\
\text { Goswami } \\
{[12]}\end{array}$ & N/E & $\begin{array}{c}240 \text { horizontal } \\
\text { tubes } \\
\mathrm{d}_{\mathrm{i}}=2.375 \mathrm{~mm} ; \\
\mathrm{d}_{\mathrm{o}}=3.175 \mathrm{~mm} \\
\mathrm{l}=98 \mathrm{~mm} \\
\mathrm{~A}=0.24 \mathrm{~m}^{2} ; \\
\mathrm{V}=4.84 \times 10-3 \mathrm{~m}^{3}\end{array}$ & $\begin{array}{l}\text { Aluminum } \\
\text { vessel } \\
\text { Stainless } \\
\text { steel tubes }\end{array}$ & $\begin{array}{l}\text { Ammonia-water } \\
\text { solution } \\
\text { Cooling water }\end{array}$ & $\begin{array}{l}\text { Countercurrent } \\
\text { flow for liquid- } \\
\text { gas contact } \\
\text { Cross- } \\
\text { countercurrent } \\
\text { flow for heat } \\
\text { exchange }\end{array}$ & $\begin{array}{c}\text { A screen mesh/ } \\
\text { fabric stretched } \\
\text { in between } \\
\text { horizontal tubes } \\
\text { Wire diameter } \\
\text { of } 0.2 \mathrm{~mm} \text { with } \\
\begin{array}{c}16 \times 16 \text { meshes / } \\
\text { inch2 }\end{array}\end{array}$ & $\begin{array}{l}\text { UA value found } \\
\text { to increase } \\
\text { by about } \\
50 \% \pm 17 \% \\
\text { with the } \\
\text { introduction } \\
\text { of the screen } \\
\text { mesh }\end{array}$ & $\begin{array}{c}\sim 103 \\
\text { (with } \\
\text { screen } \\
\text { mesh) } \\
\sim 72 \\
\text { (without } \\
\text { mesh) }\end{array}$ \\
\hline $\begin{array}{c}\text { Lee et al. } \\
\text { [19] }\end{array}$ & E & $\begin{array}{c}24 \text { horizontal } \\
\text { tubes in } 6 \text { rows } \\
\text { and } 4 \text { columns } \\
\mathrm{d}_{\mathrm{i}}=8.1 \mathrm{~mm} ; \\
\mathrm{d}_{\mathrm{o}}=9.5 \mathrm{~mm} ; \\
\mathrm{l}=292 \mathrm{~mm} \\
\mathrm{~A}=0.21 \mathrm{~m}^{2} ; \\
\mathrm{V}=3.53 \times 10-2 \mathrm{~m}^{3}\end{array}$ & $\begin{array}{l}\text { Stainless } \\
\text { steel outer } \\
\text { shell } \\
\text { Stainless } \\
\text { steel tubes }\end{array}$ & $\begin{array}{l}\text { Ammonia-water } \\
\text { solution } \\
\text { Cooling water }\end{array}$ & $\begin{array}{l}\text { Co-current flow } \\
\text { for liquid-gas } \\
\text { contact } \\
\text { Cross- } \\
\text { countercurrent } \\
\text { flow for heat } \\
\text { exchange }\end{array}$ & - & - & 7.7 \\
\hline $\begin{array}{c}\text { Curries et } \\
\text { al. [7] }\end{array}$ & E & $\begin{array}{c}\text { Single vertical } \\
\text { concentric shell } \\
\text { and tube } \\
\mathrm{d}_{\mathrm{o}}=22 \mathrm{~mm} ; \mathrm{l}=0.8 \\
\mathrm{~m} \\
\mathrm{~A}=0.06 \mathrm{~m}^{2} ; \\
\mathrm{V}=0.3 \times 10-3 \mathrm{~m}^{3}\end{array}$ & $\begin{array}{l}\text { Stainless } \\
\text { steel tube } \\
\text { Copper shell }\end{array}$ & $\begin{array}{l}\text { Tube side: LiBr solution } \\
\text { and steam } \\
\text { Shell side: gas }\end{array}$ & $\begin{array}{l}\text { Countercurrent } \\
\text { flow for } \\
\text { solution-gas } \\
\text { contact } \\
\text { Countercurrent } \\
\text { flow for heat } \\
\text { exchange }\end{array}$ & $\begin{array}{c}\text { Tube side: } \\
\text { "Heatex" inserts } \\
\text { constructed form } \\
\text { looped, } 22 \text { gauge, } \\
\text { stainless wire } \\
\text { Shell side: } \\
\text { extended surface } \\
\text { area } 50 \text { times } \\
\text { than that of a } \\
\text { plain tube }\end{array}$ & $\begin{array}{l}14 \text { times } \\
\text { higher heat } \\
\text { transfer } \\
\text { compared to } \\
\text { plain tubes }\end{array}$ & 40 \\
\hline $\begin{array}{l}\text { Bourouis et } \\
\text { al. [27] }\end{array}$ & E & $\begin{array}{c}\text { Single vertical } \\
\text { concentric shell } \\
\text { and tube } \\
\mathrm{d}_{\mathrm{i}}=22.1 \mathrm{~mm} ; \\
\mathrm{l}=1.5 \mathrm{~m}\end{array}$ & $\begin{array}{l}\text { Stainless } \\
\text { steel }\end{array}$ & $\begin{array}{c}\text { Tube side: water- } \\
\text { (LiBr+LiI+LiNO3+LiCl) } \\
\text { Shell side: cooling water }\end{array}$ & $\begin{array}{l}\text { Countercurrent } \\
\text { flow for } \\
\text { solution-gas } \\
\text { contact } \\
\text { Countercurrent } \\
\text { flow for heat } \\
\text { exchange }\end{array}$ & $\begin{array}{l}\mathrm{LiBr} \text { solution } \\
\text { with additive }\end{array}$ & $\begin{array}{l}\text { Thermal load } \\
\text { and mass } \\
\text { absorption flux } \\
\text { increased by } \\
28 \% \text { and } 50 \% \text {, } \\
\text { respectively } \\
\text { with additive }\end{array}$ & - \\
\hline $\begin{array}{c}\text { Vallès et al. } \\
\text { [9] }\end{array}$ & E & $\begin{array}{c}\text { Plate heat } \\
\text { exchanger; } \\
\text { CB76L, 60 plates; } \\
\mathrm{A}=5.5 \mathrm{~m}^{2} ; \\
\mathrm{V}=21.2 \times 10-3 \mathrm{~m}^{3}\end{array}$ & AISI316 & $\begin{array}{l}\text { Organic fluid } \\
\text { mixtures: methanol- } \\
\text { tetraethyleneglycol } \\
\text { dimethylether } \\
\text { (TEGDME) and } \\
\text { trifluoroethanol (TFE)- } \\
\text { TEGDME } \\
\text { Cooling water }\end{array}$ & $\begin{array}{l}\text { Countercurrent } \\
\text { for heat } \\
\text { exchange }\end{array}$ & $\begin{array}{c}\text { Independent } \\
\text { spray nozzle } \\
\text { (spiral, whirljet, } \\
\text { hollowjet, fulljet) } \\
\text { to spray week } \\
\text { solution into } \\
\text { the refrigerant } \\
\text { vapour }\end{array}$ & $\begin{array}{l}\text { Improved mass } \\
\text { transfer by the } \\
\text { spray nozzle } \\
\text { Limited } \\
\text { absorption } \\
\text { due to high } \\
\text { pressure drop }\end{array}$ & 43.8 \\
\hline $\begin{array}{l}\text { Kim and } \\
\text { Ferreira } \\
\text { [2008] }\end{array}$ & E & $\begin{array}{c}\text { Falling film plate; } \\
\text { Single vertical } \\
\text { plate }(95 \times 540 \\
m 2) \\
A=0.051 \mathrm{~m}^{2} ; \\
\mathrm{V}=15.9 \times 10-3 \mathrm{~m}^{3}\end{array}$ & $\begin{array}{l}\text { Glass vessel } \\
\text { Copper plate }\end{array}$ & LiBr solution and steam & $\begin{array}{l}\text { Co-current flow } \\
\text { for liquid-gas } \\
\text { contact } \\
\text { Countercurrent } \\
\text { flow for heat } \\
\text { exchange }\end{array}$ & $\begin{array}{c}\text { Copper wire } \\
\text { screen (22 } \\
\text { meshes per inch) } \\
\text { on plate surface; } \\
\text { 2-EH as additive }\end{array}$ & $\begin{array}{l}\text { Heat transfer } \\
\text { enhanced by } \\
\text { twice, mass } \\
\text { transfer } \\
\text { enhanced } \\
\text { by } 2.5 \text { and } \\
3.5 \text { times by } \\
\text { additive } \\
\text { Marginal } \\
\text { enhancement } \\
\text { by wire screen }\end{array}$ & - \\
\hline $\begin{array}{l}\text { Jenks and } \\
\text { Narayanan } \\
\quad[14]\end{array}$ & E & $\begin{array}{c}\text { Microchannel } \\
\text { HEX-absorber; } \\
\text { Cooling side } \\
\text { channel } \\
\text { dimension: } \\
10 \times 2 \times 0.88 \mathrm{~cm} 3 \\
\mathrm{~A}=0.002 \mathrm{~m}^{2} ; \\
\mathrm{V}=0.78 \times 10-3 \mathrm{~m}^{3}\end{array}$ & $\begin{array}{l}\text { Polyethere } \\
\text { therketone }\end{array}$ & $\begin{array}{l}\text { Ammonia-water } \\
\text { solution } \\
\text { Cooling water }\end{array}$ & $\begin{array}{l}\text { Crossflow } \\
\text { for liquid-gas } \\
\text { contact } \\
\text { Countercurrent } \\
\text { flow for heat } \\
\text { exchange }\end{array}$ & $\begin{array}{l}\text { Stainless-steel } \\
\text { sintered porous } \\
\text { plate }(0.5 \mu \mathrm{m} \\
\text { pore size) for gas } \\
\text { bubbling } \\
\text { Microchannel } \\
\text { (smooth or } \\
\text { ribbed) for heat } \\
\text { exchange }\end{array}$ & $\begin{array}{l}\text { Highest U } \\
\text { observed } \\
\text { for } 400 \mu \mathrm{m} \\
\text { smooth } \\
\text { microchannel } \\
\text { absorber }\end{array}$ & $\sim 7.7$ \\
\hline
\end{tabular}




\section{Recent Advances in Petrochemical Science}

\begin{tabular}{|c|c|c|c|c|c|c|c|c|}
\hline $\begin{array}{l}\text { Cerezo et } \\
\text { al. [15] }\end{array}$ & E & $\begin{array}{c}\text { Bubble plate; } \\
\text { model NB51, } \\
\text { type L with three } \\
\text { plates } \\
A=0.1 \mathrm{~m}^{2} \\
\mathrm{~V}=1 \times 10-3 \mathrm{~m}^{3}\end{array}$ & $\begin{array}{l}\text { Stainless- } \\
\text { steel }\end{array}$ & $\begin{array}{l}\text { Ammonia-water } \\
\text { solution } \\
\text { Cooling water }\end{array}$ & $\begin{array}{l}\text { Co-current flow } \\
\text { for liquid-gas } \\
\text { contact } \\
\text { Countercurrent } \\
\text { flow for heat } \\
\text { exchange }\end{array}$ & $\begin{array}{l}\text { Corrugated plate } \\
\text { Bubble injection }\end{array}$ & $\begin{array}{c}\mathrm{h}(\mathrm{film}) \text { around } \\
2.7-5.5 \mathrm{~kW} \cdot \mathrm{m}- \\
2 \cdot \mathrm{K}-1 \\
\mathrm{~kL} \text { around } \\
0.001-0.002 \\
\mathrm{~m} \cdot \mathrm{s}-1\end{array}$ & - \\
\hline $\begin{array}{l}\text { Oronel et } \\
\text { al. [16] }\end{array}$ & E & $\begin{array}{c}\text { Bubble plate; } \\
\text { chevron-L type } \\
\text { corrugation; } 4 \\
\text { plates making } 3 \\
\text { channels } \\
A=0.1 \mathrm{~m}^{2} ; \\
\mathrm{V}=\sim 1.1 \times 10^{-3} \mathrm{~m}^{3}\end{array}$ & $\begin{array}{l}\text { Stainless- } \\
\text { steel }\end{array}$ & $\begin{array}{l}\text { NH3/LiNO3 or NH3/ } \\
\text { (LiNO3+H2O) } \\
\text { Cooling water }\end{array}$ & $\begin{array}{l}\text { Co-current flow } \\
\text { for liquid-gas } \\
\text { contact } \\
\text { Countercurrent } \\
\text { flow for heat } \\
\text { exchange }\end{array}$ & $\begin{array}{l}\text { Corrugated plate } \\
\text { Ternary mixture } \\
\text { to reduce the } \\
\text { viscosity }\end{array}$ & $\begin{array}{c}\text { Mass } \\
\text { absorption } \\
\text { flux 1.3-1.6 } \\
\text { times higher; } \mathrm{h} \\
\text { (film) 1.4 times } \\
\text { higher than } \\
\text { those of binary } \\
\text { mixture }\end{array}$ & - \\
\hline $\begin{array}{c}\text { Meacham } \\
\text { and } \\
\text { Garimella } \\
{[46]}\end{array}$ & E & $\begin{array}{c}\text { Microchannel } \\
\text { array, } 660 \text { tubes } \\
\text { in total } \\
\mathrm{d}_{\mathrm{i}}=1.168 \mathrm{~mm} ; \\
\mathrm{d}_{\mathrm{o}}=1.575 \mathrm{~mm} ; \\
\mathrm{l}=0.137 \mathrm{~m} \\
\mathrm{~A}=0.456 \mathrm{~m}^{2} ; \\
\mathrm{V}=\sim 8.2 \times 10^{-3} \mathrm{~m}^{3}\end{array}$ & $\begin{array}{l}\text { Stainless- } \\
\text { steel }\end{array}$ & $\begin{array}{l}\text { Ammonia-water } \\
\text { solution } \\
\text { Cooling water }\end{array}$ & $\begin{array}{l}\text { Countercurrent } \\
\text { flow for } \\
\text { solution-gas } \\
\text { contact } \\
\text { Cross- } \\
\text { countercurrent } \\
\text { flow for heat } \\
\text { exchange }\end{array}$ & $\begin{array}{l}\text { Microchannel } \\
\text { array arranged } \\
\text { in parallel and in } \\
\text { series; } \\
\text { Improved dip } \\
\text { tray }\end{array}$ & $\begin{array}{c}\mathrm{U} \sim 545 \text { to } 940 \\
\mathrm{~W} \cdot \mathrm{m}-2 \cdot \mathrm{K}-1\end{array}$ & $\sim 41.3$ \\
\hline $\begin{array}{l}\text { Chen et al. } \\
\text { [11] }\end{array}$ & $\mathrm{N}$ & $\begin{array}{l}\text { Hybrid hollow } \\
\text { fiber membrane } \\
\text { HEX-absorber } \\
\text { (HFMAE) }\end{array}$ & $\begin{array}{l}\text { Porous fibers } \\
\text { for solution } \\
\text { gas mixing } \\
\text { Nonporous } \\
\text { fibers } \\
\text { for heat } \\
\text { exchange }\end{array}$ & Ammonia-water & Countercurrent & $\begin{array}{l}\text { Higher } \\
\text { interfacial area } \\
\text { for heat and } \\
\text { mass transfers }\end{array}$ & $\begin{array}{l}\text { COP increased } \\
\text { by } 14.8 \% \text { and } \\
\text { exergy loss } \\
\text { reduced by } \\
26.7 \% \text { when } \\
\text { compared to } \\
\text { a falling film } \\
\text { plate heat } \\
\text { exchanger }\end{array}$ & - \\
\hline $\begin{array}{l}\text { Olarte- } \\
\text { Cortés et al. } \\
{[17]}\end{array}$ & E & $\begin{array}{c}\text { Graphite disks } \\
\text { HEX-absorber } \\
18 \text { tar- } \\
\text { impregnated } \\
\text { graphite } \\
\text { disks, outside } \\
\text { diameter }=0.1 \\
\mathrm{~m} ; \mathrm{A}=0.18 \mathrm{~m}^{2} \\
\mathrm{~V}=1.27 \times 10^{-3} \mathrm{~m}^{3}\end{array}$ & $\begin{array}{l}\text { Stainless- } \\
\text { steel for the } \\
\text { column } \\
\text { tar- } \\
\text { impregnated } \\
\text { graphite } \\
\text { disks }\end{array}$ & $\begin{array}{l}\mathrm{LiBr} \text { solution and steam } \\
\text { Cooling water }\end{array}$ & $\begin{array}{l}\text { Countercurrent } \\
\text { flow for } \\
\text { solution-gas } \\
\text { contact } \\
\text { Countercurrent } \\
\text { flow for heat } \\
\text { exchange }\end{array}$ & $\begin{array}{l}\text { High thermal } \\
\text { conductivity of } \\
\text { tar-impregnated } \\
\text { graphite }(50-80 \\
\text { W.m- } 1 \cdot \mathrm{K}-1) \\
\text { Resistance } \\
\text { to corrosion } \\
\text { and to high } \\
\text { temperature }\end{array}$ & $\begin{array}{c}\mathrm{h}(\text { film) around } \\
723-1535 \\
\mathrm{~W} \cdot \mathrm{m}-2 \cdot \mathrm{K}-1 \\
\mathrm{U} \text { around } 168- \\
317 \mathrm{~W} \cdot \mathrm{m}-2 \cdot \mathrm{K}-1\end{array}$ & $\sim 3.44$ \\
\hline
\end{tabular}

The transport mechanism in such device involves the contact and mixing between absorbent solution and the absorbat vapor on one hand, and the heat exchange between the solution and the coolant fluid on the other hand. As a result, conjugated and complicated heat and mass transfer occurs in such HEX-absorbers. A variety of geometries of HEX-absorber have been proposed and studied, including horizontal tubes, vertical tubes, plate type and others. Different techniques were employed, as presented in (Table 1) to intensify the heat and mass transfers.

\section{Horizontal Tubes}

In horizontal tubes configuration, a fluid distributor is generally installed above the tubes to spray liquid droplets which then flow down by gravity to form liquid film outside the tubes. Vapor is usually generated at the bottom of the shell and

then rises and contacts with the liquid film in a countercurrent manner. Coolant fluid circulates inside the tubes to evacuate the absorption heat. Depending on the arrangement of tubes in serpentine [6-8], in parallel (Yoon et al. 2002) or mixed [9-11] the heat exchange could be in cross-countercurrent or in pure cross flow manner.
For this configuration, the wettability of falling film is of great importance to the absorption performance, so that usually structured tube external surfaces are employed [12]. These complex surface structures include finned tubes, knurled tubes [6], micro-scale hatched tubes $[13,7]$, hydrophilic tubes and floral tubes. Most studies reported improved wettability and transfer coefficients with structured surface tubes. However, it is also reported that on the presence of surfactant, the effect of structured surface may be negligible or even negative because it might actually degrade the convective mixing action of the surfactant [12].

Helical coil pipe HEX-absorbers are also proposed as a special case of the horizontal tubes type since the tubes are slightly inclined to the falling film direction [14-18]. Solution usually trickles down as a falling film outside of the coil while the coolant circulates inside the helical coil in concurrent or countercurrent flow $[19,20]$. The absorber could be operated in different modes, either concurrent or countercurrent flow of refrigerant and solution. It is generally considered that the helical arrangement makes the system more compact compared to the conventional horizontal tubes type. 


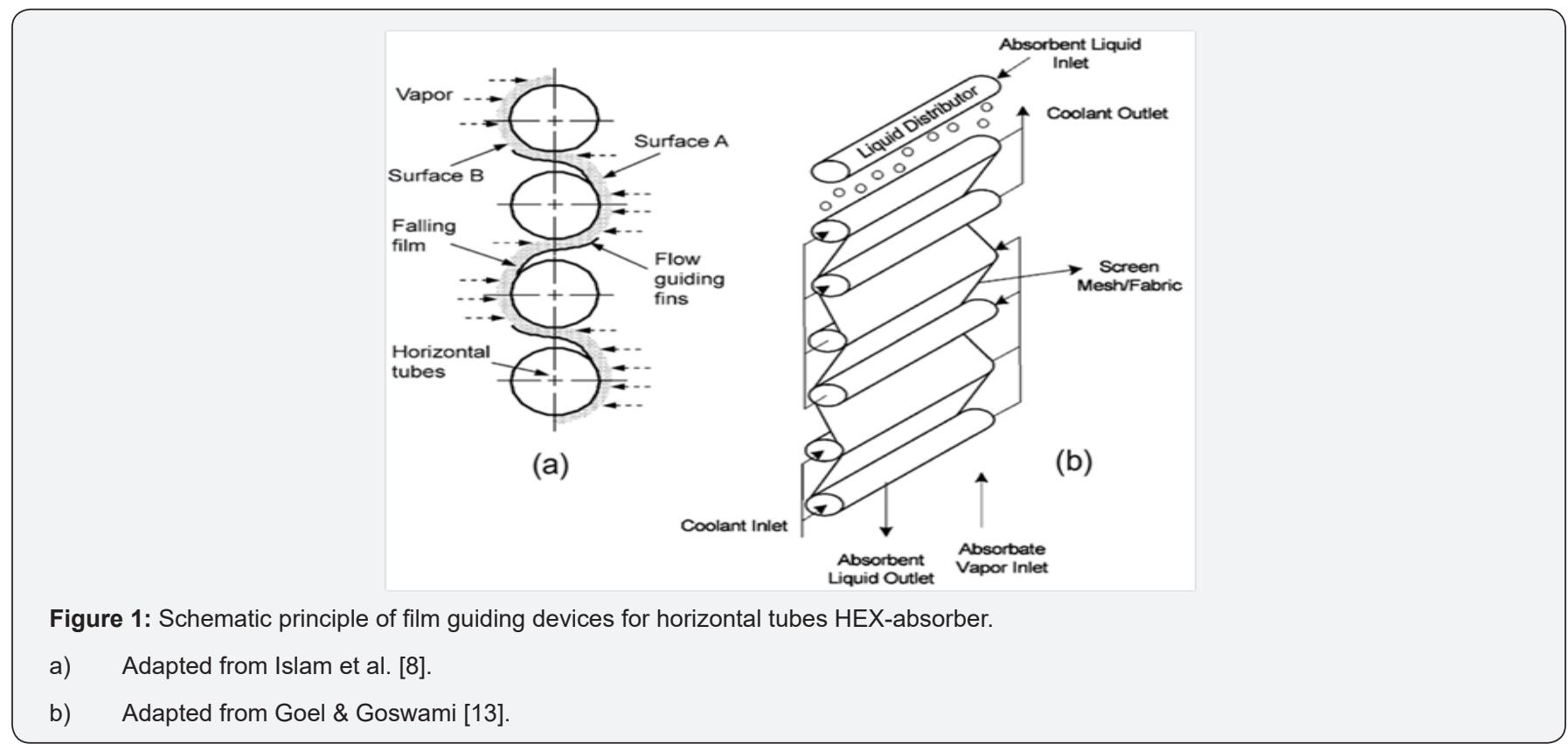

To further augment the transfer surface area, film guiding devices were introduced as shown in (Figure 1) Islam et al. [10] introduced film-guiding fins between tubes to produce a film inverting arrangement. Experimental results showed that the vapor absorption rate with the film inverting arrangement could be doubled compared to that of conventional tubular absorber [21]. Also proposed using a screen mesh/fabric stretched between the horizontal tubes for the establishment of a double sided falling film. The mesh was made of aluminum woven wire, wire diameter being $0.2 \mathrm{~mm}$ with a density of $16 \times 16$ meshes per square inches. Experimental results on ammonia-water absorption [9]. indicated about 50\% $\pm 17 \%$ increase on UA value with the introduction of screen mesh.

\section{Vertical Tubes}

In vertical tubes configuration, the falling film of solution can be formed in outer or inner surfaces of tube(s). In the former case [22] the absorbent solution flows down the outside of the inner tube to absorb the upward flowing vapor, while the absorption heat is removed by the upward flow of cooling water inside the tube. In the latter case [23-26]. Falling film is formed inside the vertical tube and the vapor flowing concurrently upward. Cooling water or gas flows upward in annulus (or in shell) to remove the absorption heat. Most of the studies on this configuration employ smooth tube(s), with the exception. who used "Heatex" inserts as turbulence promoter inside the tube and extended external surface area to enhance heat transfer. 14 times higher heat transfer is observed compared to that of plain tubes. When multiple tubes are involved, absorption in bubble mode is recommended for easier vapor distribution than liquid distribution needed in the falling film mode. Moreover, bubble mode doesn't have wettability problem. In bubble mode, solution and vapor enter at the bottom of the tubes and flow upward concurrently, the liquid-gas two phase flow pattern being successively churn flow, slug flow, and bubbly flow. The coolant could flow in countercurrent manner for concentric tubes [27] or in cross-countercurrent manner in the shell side [28].

\section{Plate-Type}

In recent years, plate-type heat exchangers have been used as absorber due to their high compactness and enhanced heat and mass transfer. The solution vapor contact could be realized in falling film mode [29,30] or in bubble mode [31-33]. To improve the performance of absorbers, different surface structures such as wire screen (Kim and Ferreira), micro ribs or fins [34] or corrugated chevrons [31,32] have been applied to the external or internal surfaces of plates. Cui et al. [35] also proposed a film-inverting configuration, analogue to the principle shown in Fig. X, for plate falling film HEX-absorber.

Vallès et al. [36] presented a plate HEX-absorber consisting of a mixing chamber with a spray of solution into the refrigerant vapor. A two-phase mixture was formed and entered into a plate HEX, where the solution is cooled. Different types of spray nozzles were studied, including spiral type, whirl jet type, hollow jet type and full jet type. Improved heat and mass transfer was observed with a thermal compatibility about 43.8 $\mathrm{kW} \cdot \mathrm{m}^{-3} \cdot \mathrm{K}^{-1}$.

\section{Novel Designs}

Garimella et al. [37-39] developed a micro channel arrays heat and mass exchanger for absorption application. The novel miniaturized device consists of short lengths of micro channels arranged in multiple square arrays, with successive arrays oriented transversely perpendicular to the adjacent 
arrays as shown in (Figure 2). Vapor generated at the bottom of the device flows upward countercurrent to the solution in falling film outside the micro channels. Coolant flows through individual tubes in arrays, from bottom to the top of the device in cross flow-countercurrent manner to the solution. Due to the small size of the micro channels, the tube-side heat transfer coefficient is extremely high while the pressure drop is relatively low because of the parallel arrangement. Experimental results with ammonia-water absorption showed an overall heat transfer coefficient of about 133 to $403 \mathrm{~W} \cdot \mathrm{m}$ $2 \cdot \mathrm{K}-1$ [38]. Further enhancement could be achieved by improved wettability of the falling film (U 545 to $940 \mathrm{~W} \cdot \mathrm{m}-2 \cdot \mathrm{K}-1,[39])$. or by a modified dripper tray and a rotated orientation (U 540 to $1160 \mathrm{~W} \cdot \mathrm{m}-2 \cdot \mathrm{K}-1,[37])$.

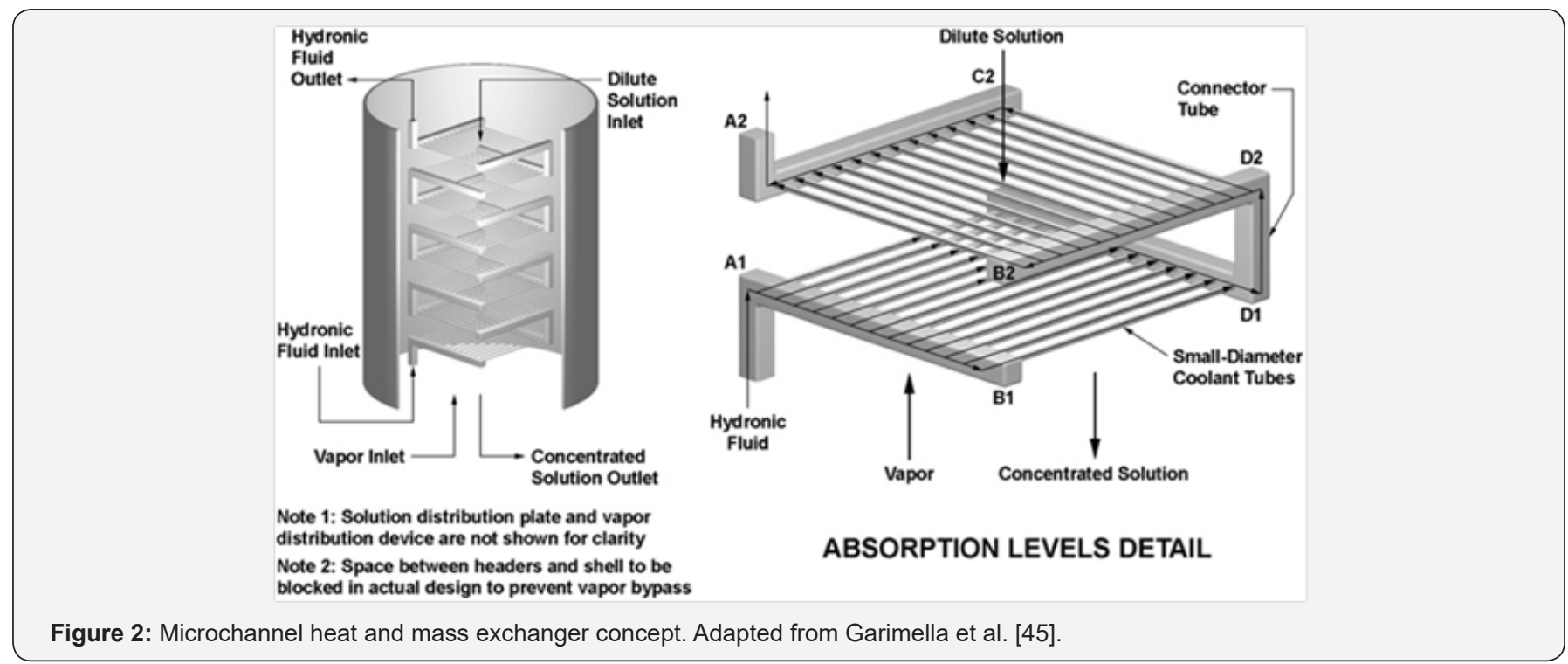

Figure 2: Microchannel heat and mass exchanger concept. Adapted from Garimella et al. [45].

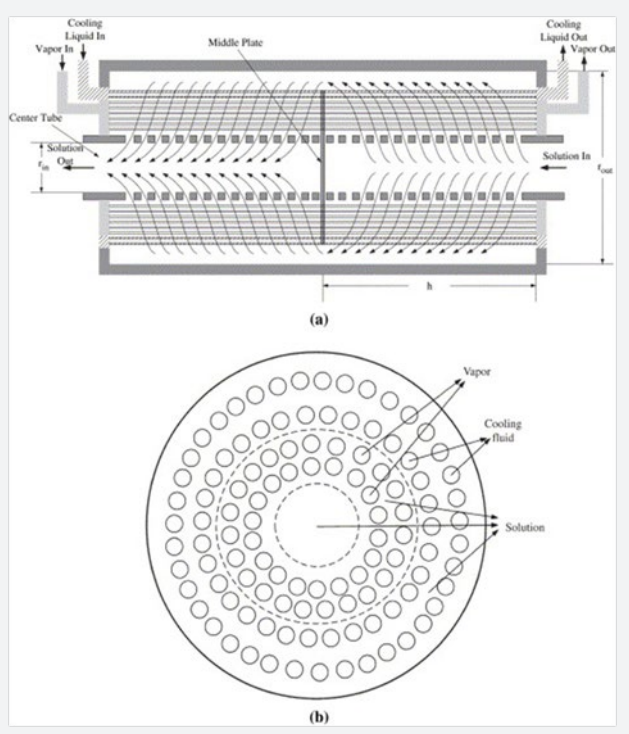

Figure 3: Hollow fiber membrane module as a hybrid absorber and heat exchanger. Adapted from Chen et al. [11].

Chen et al. [40] proposed a novel hybrid hollow fiber membrane HEX-absorber, as shown in (Figure 3). Two types of fibers are used in this hybrid device: porous fibers permit the mixing of absorption solution and vapor (countercurrent or concurrent) while nonporous fibers form material interface for heat exchange between absorption solution and cooling fluid (countercurrent). The high interfacial area of fibers enhances the heat and mass transfer so that $14.8 \%$ increase on COP can be obtained compared to that of a falling film plate heat exchanger.
Olarte-Cortés et al. [41] developed a novel HEX-absorber with stainless-steel shell and graphite disks laminated internally in a column to carry out the LiBr-water absorption. The structure of the HEX-absorber is shown in (Figure 4). Rich solution of LiBr enters through the top of the device and descends through the disks where it gets distributed, while the water vapor enters through the bottom of the device and contact with the descending solution. Cooling water circulates in the annul space between the column wall and the disks in a countercurrent manner regarding the solution [42-44]. The 
main intensification action in this HEX-absorber is the use of tar-impregnated graphite disks as the support for heat and mass transfers. This kind of corrosion resistant material has a high thermal conductivity $(50-80 \mathrm{~W} \cdot \mathrm{m}-1 \cdot \mathrm{K}-1)$ that favors the heat transfer. Moreover, the roughness of disk surface serves as micro-fins which augment the heat transfer surface area. The wetting of the surface can also be improved, providing larger interfacial area for liquid gas contact [45-47]. Experimental results showed that the $\mathrm{U}$ ranged from 168 to $317 \mathrm{~W} \cdot \mathrm{m}-2 \cdot \mathrm{K}-1$. The thermal compatibility could reach about $3.44 \mathrm{~kW} \cdot \mathrm{m}-3 \cdot \mathrm{K}-1$.

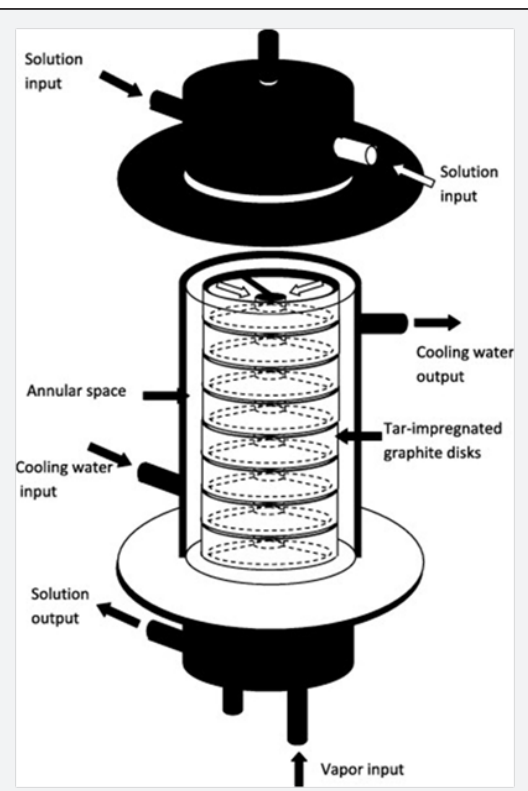

Figure 4: Structure of the graphite disks absorber and its connections. Adapted from Olarte-Cortés et al. [17].

\section{References}

1. Yu N, Wang RZ, Wang LW (2013) Sorption thermal storage for solar energy. Progress in Energy and Combustion Science 39(5): 489-514.

2. Deng J, Wang RZ, Han GY (2011) A review of thermally activated cooling technologies for combined cooling, heating and power systems. Progress in Energy and Combustion Science 37(2):172-203.

3. Fan Y, Luo L, Souyri B (2007) Review of solar sorption refrigeration technologies: Development and applications. Renewable and Sustainable Energy Reviews 11(8): 1758-1775.

4. Ma Q, Luo L, Wang RZ, Sauce G (2009) A review on transportation of heat energy over long distance: Exploratory development. Renewable and Sustainable Energy Reviews 13(6-7): 1532-40.

5. N'Tsoukpoe KE, Liu H, Le Pierrès N, Luo L (2009) A review on longterm sorption solar energy storage. Renewable and Sustainable Energy Reviews 13(9): 2385-2396.

6. Hoffmann L., Greiter I, Wagner A, Weiss V, Alefeld G (1996) Experimental investigation of heat transfer in a horizontal tube falling film absorber with aqueous solutions of $\mathrm{LiBr}$ with and without surfactants. International Journal of Refrigeration 19: 331-341.

7. Currie JS, Low RE, Pritchard CL (1996) The performance of novel compact heat exchangers with highly extended surfaces. Appl Therm Eng 16(3): 245-254.

8. Park CW, Kim SS, Cho HC, Kang YT (2003) Experimental correlation of falling film absorption heat transfer in micro-scale hatched tubes. Int J Refrig 26(7): 758-763.

9. Vallès M, Bourouis M, Boer D, Coronas A (2003) Absorption of organic fluid mixtures in plate heat exchangers. International Journal of Thermal Sciences 42(1): 85-94.

10. Islam MR, Wijeysundera NE, Ho JC (2003) Performance study of a falling-film absorber with a film-inverting configuration. Int J Refrig 26(8): 909-917.

11. Chen J, Chang H, Chen S (2006) Simulation study of a hybrid absorberheat exchanger using hollow fiber membrane module for the ammoniawater absorption cycle. Int J Refrig 29(6):1043-52.

12. Goel N, Goswami DY (2007) Experimental verification of a new heat and mass transfer enhancement concept in a microchannel falling film absorber. Journal of Heat Transfer 129(2): 154-161.

13. Goel N, Goswami DY (2005) A compact falling film absorber. Journal of Heat Transfer. The American society of Mechanical Engineers 127(9): 957-65.

14. Jenks J, Narayanan V (2008) Effect of channel geometry variations on the performance of a constrained microscale-film ammonia-water bubble absorber. Journal of Heat Transfer 130(11): 1-9.

15. Cerezo J, Bourouis M, Vallès M, Coronas A, Best R (2009) Experimental study of an ammonia-water bubble absorber using a plate heat exchanger for absorption refrigeration machines. Appl Therm Eng 29(5-6): 1005-1011.

16. Oronel C, Amaris C, Bourouis M, Vallès M (2013) Heat and mass transfer in a bubble plate absorber with NH3/LiNO3 and NH3/(LiNO3 + H2O) mixtures. International Journal of Thermal Sciences 63: 105-114.

17. Olarte-Cortés J, Torres-Merino J, Siqueiros J (2013) Experimental study of a graphite disks absorber couple to a heat transformer. Exp Therm Fluid Sci 46: 29-36.

18. Killion JD, Garimella S (2003) A review of experimental investigations of absorption of water vapor in liquid films falling over horizontal tubes. HVAC and R Research 9(2): 111-136.

19. Lee S, Bohra LK, Garimella S, Nagavarapu AK (2012) Measurement of absorption rates in horizontal-tube falling-film ammonia-water absorbers. Int J Refrig 35(3): 613-632. 
20. Determan MD, Garimella S (2011) Ammonia-water desorption heat and mass transfer in microchannel devices. Int J Refrig 34(5): 1197 208

21. Bredow D, Jain P, Wohlfeil A, Ziegler F (2008) Heat and mass transfer characteristics of a horizontal tube absorber in a semi-commercial absorption chiller. Int J Refrig 31(7): 1273-1281.

22. Kim J, Park CW, Kang YT (2003) The effect of micro-scale surface treatment on heat and mass transfer performance for a falling film H20/LiBr absorber. Int J Refrig 26(5): 575-585.

23. Fujita T (2012) Falling liquid films in absorption machines. Int J Refrig 5(1): 15-26.

24. Kim KJ, Berman NS, Chau DSC, Wood BD (1995) Absorption of water vapour into falling films of aqueous lithium bromide. Int J Refrig 18(7): 486-494.

25. Medrano M, Bourouis M, Coronas A (2002) Absorption of water vapour in the falling film of water-lithium bromide inside a vertical tube at aircooling thermal conditions. International Journal of Thermal Sciences 41(9): 891-898.

26. Medrano M, Bourouis M, Perez-Blanco H, Coronas A (2013) A simple model for falling film absorption on vertical tubes in the presence of non-absorbables. Int J Refrig 26(1): 108-1016.

27. Bourouis M, Vallès M, Medrano M, Coronas A (2005) Absorption of water vapour in the falling film of water- $\left(\mathrm{LiBr}+\mathrm{LiI}+\mathrm{LiNO}_{3}+\mathrm{LiCl}\right)$ in a vertical tube at air-cooling thermal conditions. International Journal of Thermal Sciences 44(5): 491-498.

28. Takamatsu H, Yamashiro H, Takata N, Honda H (2003) Vapor absorption by $\mathrm{LiBr}$ aqueous solution in vertical smooth tubes. Int J Refrig 26(6): 659-666.

29. Fu Lin SJ, Shigang Z (2011) Experimental study on vertical vapor absorption into LiBr solution with and without additive. Appl Therm Eng 31(14-15): 2850-2854.

30. Sujatha KS, Mani A, Murthy SS (1999) Experiments on a bubble absorber. Int Commun Heat Mass Transfer 26(7): 975-984

31. Fernández-Seara J, Sieres J, Rodríguez C, Vázquez M (2005) Ammoniawater absorption in vertical tubular absorbers. International Journal of Thermal Sciences 44(3): 277-88.

32. Genssle A, Stephan K (2000) Analysis of the process characteristics of an absorption heat transformer with compact heat exchangers and the mixture TFE-E181. International Journal of Thermal Sciences 39(1): 30-38.

33. Kwon K, Jeong S (2004) Effect of vapor flow on the falling-film heat and mass transfer of the ammonia/water absorber. Int J Refrig 27(8) 955-964.
34. Yoon J, Kwon O, Bansal PK, Moon C, Lee H (2006) Heat and mass transfer characteristics of a small helical absorber. Appl Therm Eng 26(2-3): 186-192.

35. Yoon J, Kwon O, Moon C, Lee H, Bansal P (2005) Heat and mass transfer characteristics of a helical absorber using $\mathrm{LiBr}$ and $\mathrm{LiBr}+\mathrm{LiI}+\mathrm{LiNO} 3+$ LiCl solutions. Int J Heat Mass Transfer 48(10): 2102-2109.

36. Nabil BH, Bechir C, Slimane G (2013) Global modeling of heat and mass transfers in spiral tubular absorber of a water-lithium bromide absorption chiller. Int J Refrig 38(1).

37. Kaynakli 0 (2008) The first and second law analysis of a lithium bromide/water coil absorber. Energy 33(5): 804-816.

38. Kaynakli O, Horuz I (2006) Comparison of parallel and counter flow coil absorber performance. Int Commun Heat Mass Transfer 33(2): 211-223.

39. Lee KB, Chun BH, Lee JC, Lee CH, Kim SH (2002) Experimental analysis of bubble mode in a plate-type absorber. Chemical Engineering Science 57(11): 1923-1929.

40. Kim DS, Infante Ferreira CA (2009) Flow patterns and heat and mass transfer coefficients of low reynolds number falling film flows on vertical plates: Effects of a wire screen and an additive. Int J Refrig 32(1): 138-149.

41. Karami S, Farhanieh B (2009) A numerical study on the absorption of water vapor into a film of aqueous $\mathrm{LiBr}$ falling along a vertical plate. Heat Mass Transfer 46(2): 197-207.

42. Cui X, Shi J, Tan C, Xu Z (2009) Investigation of plate falling film absorber with film-inverting configuration. Journal of Heat Transfer 131(7): 1-9.

43. Karami S, Farhanieh B (2011) Numerical modeling of incline plate LiBr absorber. Heat Mass Transfer 47(3): 259-267.

44. Suresh M, Mani A (2013) Heat and mass transfer studies on a compact bubble absorber in R134a-DMF solution based vapour absorption refrigeration system. Int J Refrig 36(3): 1004-1014.

45. Garimella S, Determan MD, Meacham JM, Lee S, Ernst TC (2011) Microchannel component technology for system-wide application in ammonia/water absorption heat pumps. Int J Refrig 34(5): 1184-1196.

46. Garimella S, Meacham JM (2004) Ammonia-water absorption heat and mass transfer in microchannel absorbers with visual confirmation. ASHRAE transactions 110(1): 525-532.

47. Meacham JM, Garimella S (270) Experimental demonstration of prototype microchannel absorber for space-conditioning systems. In: International Sorption Heat Pump Conference, Shanghai, China, pp. 270-276.

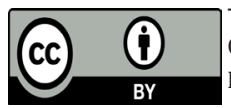

This work is licensed under Creative Commons Attribution 4.0 Licens DOI: $10.19080 /$ RAPSCI.2017.02.555581
Your next submission with Juniper Publishers will reach you the below assets

- Quality Editorial service

- Swift Peer Review

- Reprints availability

- E-prints Service

- Manuscript Podcast for convenient understanding

- Global attainment for your research

- Manuscript accessibility in different formats

( Pdf, E-pub, Full Text, Audio)

- Unceasing customer service

Track the below URL for one-step submission https://juniperpublishers.com/online-submission.php 